\title{
EFFECT OF PHYSIOLOGICAL AGE AND GROWTH REGULATORS ON CALLUS BROWNING OF COCONUT ENDOSPERM IN VITRO CULTURE
}

\author{
LAZARUS AGUS SUKAMTO* \\ Research Center for Biology - Indonesian Institute of Sciences \\ Cibinong, Indonesia
}

\begin{abstract}
The possibility of physiological age and growth regulators affecting callus browning of coconut endosperm was investigated. Solid endosperm explants of four coconut fruits from same brunches of two coconut cultivars "Samoan Dwarf" were grown on modified Murashige and Skoog (MS) formula with addition of $10 \mathrm{mg} \mathrm{l}^{-1}$ putresine, $2.50 \mathrm{gl}^{-1}$ activated charcoal (AC), $1.70 \mathrm{~g} \mathrm{l}^{-1}$ phytagel, $0,10^{-6}, 10^{-5}, 10^{-4}, 10^{-3} \mathrm{M}$ 2,4-dichlorophenoxyacetic acid (2,4-D) or 4-amino3,5,6-trichloropicolinic acid (Picloram) combined with $10^{-5} \mathrm{M}$ 6-benzylaminopurine (BA). Callogenesis occurred on $98.83 \%$ of explants. Callus browning between different physiological ages (antipodal and micropylar tissues) of coconut endosperm at 9,26 and 31 weeks of culture (WOC) was significantly different, but not at 16 and 21 WOC. Auxins of 2,4-D and Picloram did not affect significantly callus browning of endosperm cultures. Auxin doses at $10^{-6}, 10^{-5}$, and $10^{-4} \mathrm{M}$ decreased significantly callus browning at 9 and 16 WOC, respectively, but at $10^{-6} \mathrm{M}$ browning was less significant compared to other doses at 21 WOC. Auxin dose at $10^{-3} \mathrm{M}$ caused less significant browning compared to other doses at 31 WOC. The addition of BA decreased significantly callus browning at 9 WOC, but did not affect callus browning thereafter.
\end{abstract}

Key words: Coconut, invitro, Picloram, 2,4-D, BA

\section{INTRODUCTION}

Coconut (Cocos nucifera L.) is a long-lived tree with a very long juvenile phase (3 - 5 years), generally cross-pollinated and very heterozygous. Vegetative propagation in vitro through the use of various explants has been attempted but the success is mostly limited to immature unselected plants and produced very few plants. Coconut endosperm is considered a mature tissue which provides large and uniform explants without damaging mother plant for in vitro culture.

$\overline{* \text { Corresponding author : lazarus_agus@yahoo.com }}$ 
Physiological age is a critical factor for the success of in vitro culture (Ozyigit et al. 2007). The age of the endosperm at the time of culture is critical for growth in vitro (Chen et al. 1990). Explants from younger fruits responded better to culture (Karunaratne et al. 1991). However, coenocytic (free-nuclear) endosperm from very young fruits did not survive in culture because of lack of starch (Srivastava 1982). Young endosperm at celliferous stage was responsive to culture in Citrus grandis and apple (Mu and Liu 1978; Wang and Chang 1978). Endosperm of 6 - 7 months postanthesis in coconut which solid endosperm started to form in the antipodal end of coconut fruit (Tammes \& Whitehead 1969) was responsive to in vitro culture (Kumar etal.1985).

Whole plants are autonomous with regard to growth regulators but isolated tissues or cells require auxins or cytokinins to initiate and maintain growth until they become habituated or organized (Everett et al. 1978). Morphogenesis in vitro can be regulated by regulators (Christianson \& Warnick 1983), Skoog and Miller (1957) found that the balance of auxin and cytokinin in culture medium governed morphogenesis. Auxins induced callogenesis, adventitious plantlets and roots in palms (Tisserat 1979; Paranjothy \& Rohani 1982; Reynolds 1982; Paranjothy 1986). Among auxins, 2,4-D was the most effective compared to the others in coconut culture (Blake \& Euwens 1982; Pannetier \& Buffard-Morel 1986; Karunaratne \& Periyapperuma 1989). Auxin at high doses $\left(10^{-5} \mathrm{M}-10^{-3} \mathrm{M}\right)$ was necessary for callus induction in palm, especially on medium supplemented with $1-3 \mathrm{~g} \mathrm{l}^{-1}$ AC (Jesty \& Francis 1992). Another auxin with properties similar to 2,4-D is Picloram. Picloram has been successfully applied for callogenesis in date palm (Omar \& Novak 1990), embryogenesis in pejibaje palm (Valverde et al. 1987), and maintained regenerative callus over long time in sugarcane (Fitch et al. 1983). Picloram was faster than 2,4-D for callogenesis, embryo induction, and final yield of embryos in Gasteria and Hawortbia (Beyl \& Sharma 1983). On the other hand, Picloram produced more phenolics from cut surfaces and was slower for callogenesis than 2,4-D in sugarcane (Fitch et al. 1983). The presence of cytokinins, auxins, and high doses of sucrose $(0.2 \mathrm{M})$ stimulated growth of coconut and date callus (Euwens 1978). Combination of cytokinin at low dose with auxin at high dose was necessary for callogenesis of coconut embryos (Bhaskaran 1985). Srinivasan et al. (1985) successfully induced somatic embryos of Christmas palm with $5-50 \times 10^{-5} \mathrm{M} 2,4-\mathrm{D}$ and $50 \times 10^{-5} \mathrm{M} \mathrm{BA}$. BA was more effective than kinetin in stimulating callus growth in longan culture (Litz 1988), increased greatly fresh weight of coconut callus and date palm callus (Euwens 1978; Kuruvinashetti \& Iyer 1980; Sharma et al. 1984).

Explant browning is often associated with physiological age and failure of explants survival (Krishna et al. 2008; Guo et al. 2010). Browning in some explants may be very severe and causes inhibition or cessation of growth (Abdelwahd et al.2008; Misra et al. 2010). Phenolics, tannins or oxidized polyphenols are synthesized through shikimic acid, phenylpropanoid, flavonoid, and terpenoid pathways. These substances are abundantly present in some plants and act as inhibitory agents (Preece \& Compton 1991). Phenolics, especially the most common polyphenol cause oxidative browning in explants, which lead to discoloration of the culture medium (Forrest 1969; Davies 1972; Babbar \& Gupta 1986; Tang \& Newton 2004). Oxidized phenolic 
compounds are frequently exuded into the medium by injured woody tissues causing lethal browning or blackening of explants (Alderson 1987; Bhat \& Chandel 1991; Trautmann \& Visser 1991).

Immature endosperms were more responsive in in vitro culture than mature ones (Cheema \& Mehra 1982). This was partially due to oxidation products which were more abundant in the older explants (Sugimura et al. 1988; Preece \& Compton 1991; Wu et al. 2010). Activated Charcoal can promote cell growth and development, it may be mainly due to its irreversible adsorption of inhibitory compounds in the culture medium and substantially decreasing toxic metabolites, phenolic exudation and browning (Zhu et al. 1997; Thomas 2008). Browning can be reduced or eliminated through the use of liquid media, AC, silver nitrate, ascorbic acid, citric acid, sodium hydrosulfite, cystein, diethyldithio-carbamate (DTT), potassium ethylxanthate, thiourea, benzimidazole, sodium bisulfit, polyvinylpyrrolidone (PVP), polyclar, glutathione, and bovine serum albumin, more frequent transfers, incubation with reduced illumination or in complete darkness, presoaking explants in sterile water, sealing the cut ends with paraffin wax, changing medium, avoiding high temperatures, discarding explants which show browning, reducing explants thickness, and choosing the most suitable stage (Chang et al. 2001; Wu \& du Toit 2004; Mitsukuri et al. 2009).

Addition of auxins, particularly 2,4-D at high doses, led to browning of coconut leaf (Pannetier \& Buffard-Morel 1986). Sugimura and Salvana (1989) observed that 2,4-D at $2.26 \times 10^{-4} \mathrm{M}-4.52 \times 10^{-4} \mathrm{M}$ caused severe browning of tissues regardless of the stage and size of coconut inflorescence culture. 2,4-D at levels higher than $30 \times 10$

${ }^{6} \mathrm{M}$ inhibited callusing and enhanced browning of coconut embryos (Karunaratne \& Periyapperuma 1989). Callus precociously isolated from explants also caused browning and necrosis in coconut inflorescence (Verdeil et al. 1993). Addition of cytokinin, such as kinetin also caused more browning than the use of auxin in palm cultures (Reynolds 1982).

The objective of the study is to know the effect of physiological age (antipodal and micropylar) and growth regulators (2,4-D, Picloram, and BA) on callus browning of coconut endosperm in vitro culture.

\section{MATERIALS AND METHOD}

\section{Explant material}

Plant materials of four seven-month old coconut fruits were taken from two bunches of two coconut trees cultivars "Samoan Dwarf" after opening inflorescences. These fruits immediately were disinfested by using alcohol $95 \%$. The fruits were opened and their water decanted, cut horizontally with a sterile big knife.

Solid endosperms were aseptically cored with cork borer and scooped with a sterile spoon in laminar air flow. These endosperms were taken from either the micropylar region (upper half of fruit where embryo located) or the antipodal region (bottom half of fruit). Cylindrical endosperm shapes with $8 \mathrm{~mm}$ diameter and $4 \mathrm{~mm}$ thick, used as explants, were grown on various media treatments. 


\section{Media culture}

Media cultures were a modification of Branton and Blake formula (1986) added with $10 \mathrm{mgl}^{-1}$ putrescine, $2.50 \mathrm{gl}^{-1} \mathrm{AC}, 1.70 \mathrm{gl}^{-1}$ phytagel, hormones 2,4-D or Picloram at $0,10^{-6}, 10^{-5}, 10^{-4}$ and $10^{-3} \mathrm{M}$ concentrations, respectively, were combined with or without $10^{-5} \mathrm{MBA}$ at $16 \mathrm{WOC}$. The $\mathrm{pH}$ of the media were adjusted to 5.70 before they were autoclaved. The media were poured into $2.5 \times 15 \mathrm{~cm}$ test tubes $(14 \mathrm{ml})$ and autoclaved at $121^{\circ} \mathrm{C}$ temperature and $1 \mathrm{~kg} \mathrm{~cm}^{-2}$ pressure for 15 minutes. Media were stored for one week before use. Single explant was placed into test tube with the uncut surface upright. Cultures were incubated at approximately $31^{\circ} \mathrm{C}$ in the dark room.

\section{Experimental design}

The experimental design was a randomized complete block design (RCBD) with each fruit as a block. Treatments were factorial combinations of endosperm region (micropylar and antipodal), auxins (2,4-D and Picloram) and their doses $\left(0,10^{-6} \mathrm{M}, 10\right.$ ${ }^{5} \mathrm{M}, 10^{-4} \mathrm{M}, 10^{-3} \mathrm{M}$ ) and cytokinin (with or without $10^{-5} \mathrm{M} \mathrm{BA}$ ) with 12 replications. Callogenesis of coconut endosperm was counted as percentage on 31 WOC. The tissues browning were evaluated visually at every transfer using numerical scores ranging from 0 to $3(0:$ no browning, $1:$ little browning, $2:$ medium browning, and 3 : high browning) at 9, 16, 21, 26 and 31 WOC. Data were analyzed with the General Linear Models (GLM) and non parametric one way (Kruskal-Wallis test) procedure of Statistical Analysis System (SAS).

\section{RESULTS AND DISCUSSION}

\section{Callogenesis of coconut endosperm}

Coconut endosperm explants formed callus after approximately 3 WOC. Callus grew predominantly on the uncut surface and on the side of endosperms. Eventually, the callus grew and covered the entire explants. Callogenesis occurred on almost all explants with an average of $98.83 \%$ (Table 1). These results were better than those obtained by Kumar et al. (1985) i.e. 30\% of coconut endosperms, Gmitter et al. (1990) i.e. 8 - 25\% of Citrus maxima endosperms, Chen et al. (1990) i.e. $1.60-3.74 \%$ of $C$. sinensis endosperms; Pannetier and Buffard-Morel (1982) i.e. 20\% of mature coconut leaves and $50 \%$ of juvenile coconut leaves, and Verdeil et al. (1989) i.e. $45 \%$ of coconut inflorescence. The good result could be due to genetic and sterilized factors. In addition, the plant materials used in this study were different in explants type, cultivars or plants than those used by other researchers. Sterilized method was different than of Kumar et al. (1985), this experiment only sterilized the outer skin of the fruits not the explants. Therefore, the explants were more responsive in promoting callogenesis.

\section{Physiological age and calli browning}

Oxidative browning (brown to black) of endosperm calli occurred during culture. Browning varied within or among treatments, ranging from 0 : no browning, 1: slight 
Callus Browning of Coconut Endosperm in vitro Culture - L.A. Sukamto

Table 1. Percentage of callogenesis of coconut endosperm after 31 weeks of culture

\begin{tabular}{|c|c|c|c|c|c|}
\hline Source & Fruit 1 & Fruit 2 & Fruit 3 & Fruit 4 & Average \\
\hline $\begin{array}{l}\text { Endosperm } \\
\text { Position: }\end{array}$ & $98.98 \pm 0.71^{\mathrm{z} a}$ & $99.44 \pm 0.56^{\mathrm{y}} \mathrm{a}$ & $97.92 \pm 1.30 \mathrm{a}$ & $98.98 \pm 0.71 \mathrm{a}$ & 98.83 \\
\hline Antipodal & $98.89 \pm 1.11 \mathrm{a}$ & $98.89 \pm 1.11 \mathrm{a}$ & $97.69 \pm 1.88 \mathrm{a}$ & $100.00 \pm 0.00 \mathrm{a}$ & 98.87 \\
\hline $\begin{array}{l}\text { Micropylar } \\
\text { Auxin: }\end{array}$ & $99.07 \pm 0.93 \mathrm{a}$ & $100.00 \pm 0.00 \mathrm{a}$ & $98.15 \pm 1.85 \mathrm{a}$ & $97.96 \pm 1.40 \mathrm{a}$ & 98.80 \\
\hline $2,4-\mathrm{D}$ & $98.89 \pm 1.11 \mathrm{a}$ & $100.00 \pm 0.00 \mathrm{a}$ & $96.30 \pm 2.54 \mathrm{a}$ & $98.89 \pm 1.11 \mathrm{a}$ & 98.52 \\
\hline $\begin{array}{l}\text { Picloram } \\
\text { Dose: }\end{array}$ & $99.07 \pm 0.93 \mathrm{a}$ & $98.89 \pm 1.11 \mathrm{a}$ & $99.54 \pm 1.11 \mathrm{a}$ & $99.07 \pm 0.93 \mathrm{a}$ & 99.14 \\
\hline $0 \mathrm{M}$ & $100.00 \pm 0.00 \mathrm{a}$ & $100.00 \pm 0.00 \mathrm{a}$ & $97.92 \pm 2.08 \mathrm{a}$ & $100.00 \pm 0.00 \mathrm{a}$ & 99.48 \\
\hline $10^{-6} \mathrm{M}$ & $100.00 \pm 0.00 \mathrm{a}$ & $100.00 \pm 0.00 \mathrm{a}$ & $100.00 \pm 0.00 \mathrm{a}$ & $97.92 \pm 2.08 \mathrm{a}$ & 100.00 \\
\hline $10^{-5} \mathrm{M}$ & $100.00 \pm 0.00 \mathrm{a}$ & $100.00 \pm 0.00 \mathrm{a}$ & $100.00 \pm 0.00 \mathrm{a}$ & $100.00 \pm 0.00 \mathrm{a}$ & 99.48 \\
\hline $10^{-4} \mathrm{M}$ & $97.50 \pm 2.50 \mathrm{a}$ & $100.00 \pm 0.00 \mathrm{a}$ & $95.83 \pm 4.17 \mathrm{a}$ & $100.00 \pm 0.00 \mathrm{a}$ & 98.33 \\
\hline $\begin{array}{l}10^{-3} \mathrm{M} \\
\text { BA }\end{array}$ & $97.92 \pm 2.08 \mathrm{a}$ & $97.50 \pm 2.50 \mathrm{a}$ & $95.83 \pm 4.17 \mathrm{a}$ & $97.50 \pm 2.50 \mathrm{a}$ & 97.19 \\
\hline $0 \mathrm{M}$ & $99.00 \pm 1.00 \mathrm{a}$ & $99.00 \pm 1.00 \mathrm{a}$ & $99.58 \pm 0.42 \mathrm{a}$ & $99.00 \pm 1.00 \mathrm{a}$ & 99.15 \\
\hline $10^{-5} \mathrm{M}$ & $98.96 \pm 1.04 \mathrm{a}$ & $100.00 \pm 0.00 \mathrm{a}$ & $95.83 \pm 2.85 \mathrm{a}$ & $98.96 \pm 1.04 \mathrm{a}$ & 98.44 \\
\hline
\end{tabular}

Means standard error of 12 measurements

${ }^{y}$ Means in the same group followed by the same letter in a column except for the average are not significantly different at the $5 \%$ level (based on a comparison of possible combinations between the averages of treatments)

Table 2. Browning levels of coconut endosperm callus $(0:$ no browning, $1:$ light brown, $2:$ brown $3:$ dark brown)

\begin{tabular}{lcccccc}
\hline Source & & 9 weeks & 16 weeks & 21 weeks & 26 weeks & 31 weeks \\
\hline Average & & $1.18 \pm 0.03^{\mathrm{z}} \mathrm{c}$ & $1.75 \pm 0.03^{\mathrm{y}} \mathrm{b}$ & $2.25 \pm 0.02 \mathrm{a}$ & $2.23 \pm 0.02 \mathrm{a}$ & $2.18 \pm 0.03 \mathrm{a}$ \\
Position & Antipodal & $1.29 \pm 0.04 \mathrm{a}$ & $1.73 \pm 0.05 \mathrm{a}$ & $2.27 \pm 0.03 \mathrm{a}$ & $2.32 \pm 0.03 \mathrm{a}$ & $2.30 \pm 0.04 \mathrm{a}$ \\
& & & & & \\
& Micropylar & $1.07 \pm 0.04 \mathrm{~b}$ & $1.76 \pm 0.04 \mathrm{a}$ & $2.24 \pm 0.04 \mathrm{a}$ & $2.14 \pm 0.04 \mathrm{~b}$ & $2.05 \pm 0.04 \mathrm{~b}$ \\
& & & & & \\
Auxin & $2,4-\mathrm{D}$ & $1.15 \pm 0.04 \mathrm{a}$ & $1.73 \pm 0.05 \mathrm{a}$ & $2.22 \pm 0.03 \mathrm{a}$ & $2.21 \pm 0.04 \mathrm{a}$ & $2.19 \pm 0.04 \mathrm{a}$ \\
& Picloram & $1.21 \pm 0.04 \mathrm{a}$ & $1.77 \pm 0.04 \mathrm{a}$ & $2.29 \pm 0.03 \mathrm{a}$ & $2.24 \pm 0.03 \mathrm{a}$ & $2.17 \pm 0.04 \mathrm{a}$ \\
& & & & & \\
Dose & $0 \quad \mathrm{M}$ & $1.60 \pm 0.06 \mathrm{a}$ & $1.94 \pm 0.06 \mathrm{~b}$ & $2.29 \pm 0.05 \mathrm{a}$ & $2.21 \pm 0.04 \mathrm{~b}$ & $2.40 \pm 0.07 \mathrm{a}$ \\
& $10^{-6} \mathrm{M}$ & $0.93 \pm 0.06 \mathrm{~b}$ & $1.47 \pm 0.08 \mathrm{c}$ & $1.96 \pm 0.05 \mathrm{~b}$ & $2.25 \pm 0.04 \mathrm{~b}$ & $2.21 \pm 0.05 \mathrm{a}$ \\
& $10^{-5} \mathrm{M}$ & $1.03 \pm 0.06 \mathrm{~b}$ & $1.58 \pm 0.07 \mathrm{c}$ & $2.39 \pm 0.05 \mathrm{a}$ & $2.42 \pm 0.05 \mathrm{a}$ & $2.24 \pm 0.06 \mathrm{a}$ \\
& $10^{-4} \mathrm{M}$ & $0.95 \pm 0.06 \mathrm{~b}$ & $1.64 \pm 0.07 \mathrm{c}$ & $2.27 \pm 0.06 \mathrm{a}$ & $2.09 \pm 0.07 \mathrm{~b}$ & $2.17 \pm 0.07 \mathrm{a}$ \\
& $10^{-3} \mathrm{M}$ & $1.53 \pm 0.07 \mathrm{a}$ & $2.15 \pm 0.07 \mathrm{a}$ & $2.36 \pm 0.05 \mathrm{a}$ & $2.18 \pm 0.06 \mathrm{~b}$ & $1.94 \pm 0.07 \mathrm{~b}$ \\
& & & & & & $2.15 \pm 0.04 \mathrm{a}$
\end{tabular}

"Means standard error of 12 measurements

'Means in the same group followed by the same letter in a column except for the average are not significantly different at the $5 \%$ level (based on a comparison of possible combinations between the averages of treatments) 


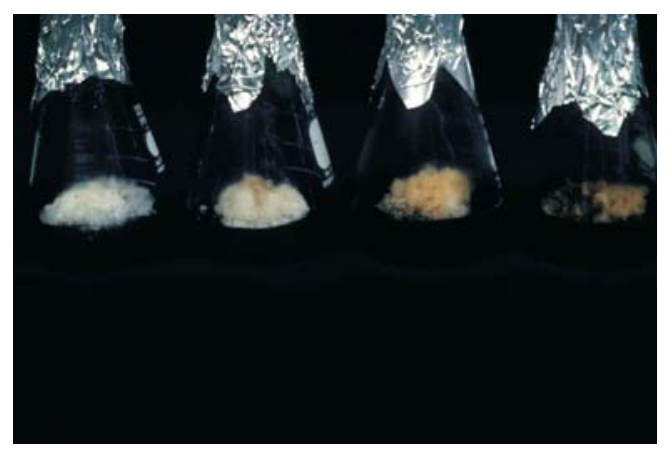

Figure 1. Browning of coconut endosperm callus at various levels i.e. 0, 1, 2, and 3 (from left to right)

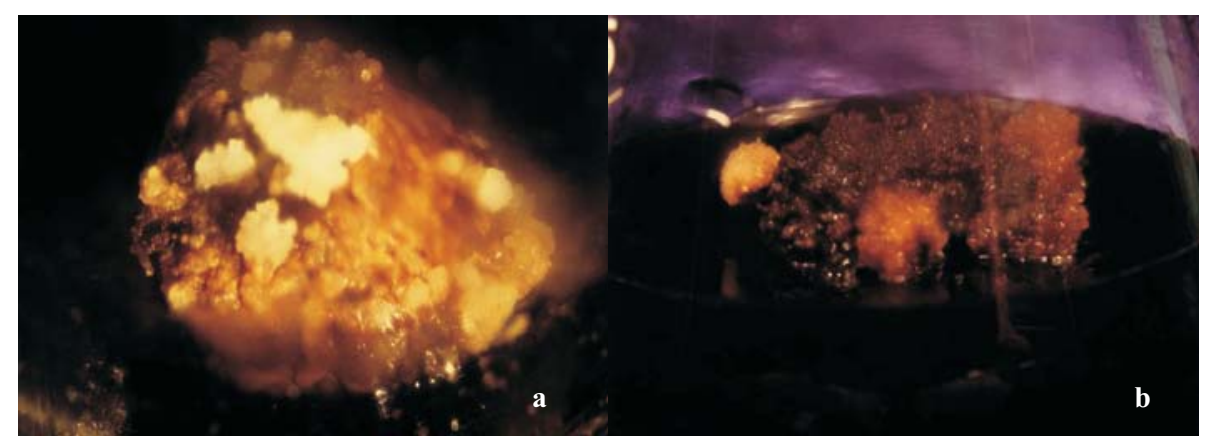

Figure 2. a). Varied colors of coconut endosperm callus, b). New yellowish white callus grown from the black callus of coconut endosperm

browning 2:medium browning, and 3: severe browning (Fig. 1). Tissue browning by all treatments was slight (score $=1.18)$ at 9 WOC. Tissue browning increased substantially (browning level $=1.75$ ) after $16 \mathrm{WOC}$ and reached maximal browning (browning level $=2.25$ ) on 21 WOC. Thereafter browning decreased slightly on 26 WOC (browning level $=2.23$ ) and $31 \mathrm{WOC}$ (browning level $=2.18$ ). Compton and Preece (1988) found that phenolic compounds exuded from excised explants were oxidized by peroxidases or polyphenolo-xidases, causing browning of both plant tissues and media. This might reduce growth or kill the tissues (Preece and Compton 1991). Severe browning of coconut endosperm still occurred even though in young explants which were not treated by disinfectants and incubated in the dark room. Whereas this condition was expected to prevent browning of Geonoma gamiova (Dias $e t$ al. 1994). The antipodal and micropylar tissues browning showed a steady increase at 21 WOC (Table 2). Statistical analysis showed that browning of antipodal tissues was more significant than in micropylar tissues at 9, 26, and 31 WOC. It could be due to antipodal tissues which were earlier formed (older) and thicker than micropylar tissues. These results support the findings of Murashige (1974) that the influence of 
physiological age on explants responses was not significantly different at 16 and 21 WOC (Table 2). Explants thickness influenced browning, antipodal explants were thicker and showed more browning compared to micropylar explants. Similar results were obtained by Sugimura and Salvana (1989) in coconut inflorescence explants of $1 \mathrm{~mm}$ which had $32 \%$ browning compared to $11 \%$ browning in $0.5 \mathrm{~mm}$ thick.coconut inflorence explants.

\section{Growth regulators and calli browning}

The two types of auxins (2,4-D and Picloram) did not cause any significant difference in browning of endosperm tissues. Different results were reported by Fitch et al. (1983) that Picloram caused more browning than 2,4-D in Saccharum spontaneum cultures. The browning levels of tissues initially treated with $10^{-3} \mathrm{M}$ auxin were significantly higher at $9 \mathrm{WOC}$, the highest at $16 \mathrm{WOC}$, and the lowest at 31 WOC than those of the other auxin concentrations (Table 2).

The browning levels of control were higher at 9-16 WOC than of those tissues treated with $10^{-6} \mathrm{M}-10^{-4} \mathrm{M}$ auxins (Table 2). The tissues initially treated with $10^{-6} \mathrm{M}$ auxin, showed significantly less browning than control or other auxin concentrations at 21 WOC. The tissues initially treated with $10^{-5} \mathrm{M}$ auxin caued significantly more browning than of the other treatments at 26 WOC. This result disagreed with the findings of Pannetier and Buffard-Morel (1986), Karunaratne and Periyapperuma (1989), and Sugimura and Salvana (1989) that 2,4-D levels higher than $3 \times 10^{-5} \mathrm{M}$ caused more browning than lower concentrations in coconut explants. This result agreed with the findings of Phillips and Henshaw (1977) in Acer pseudoplatanus cell cultures. Addition of BA significantly decreased browning at 16 WOC. Similar result was reported by Herve et al. (2001) in Eucalyptus gunnii culture. However, those of addition did not affect significantly callus browning thereafter (Table 2).

Calli color changed progressively, from white to brown, to dark brown and to black (Fig. 2a). Then new yellowish white callus grew from the black callus and this sequence was repeated through many cycles (Fig. 2b). Severe browning did not inhibit the growth of endosperm cultures. Similar result was reported by Jones (1974) in oil palm and Ettinger and Preece (1985) in Rhododendron cultures. Coconut endosperm probably tolerated high level of 2,4-D or Picloram, even their browning were less than other treatments including control at $10^{-3} \mathrm{M}$ on $31 \mathrm{WOC}$ (Table 2), due to the presence of $\mathrm{AC}$ at $2.5 \mathrm{~g}^{-1}$ in the medium and dark incubation. It agreed with the findings of Wang and Huang (1976), Fridborg et al. (1978), Tisserat (1979), Blake and Eeuwens (1982), Rao et al. (1987), Sugimura and Salvana (1989), and Krikorian (1994).

\section{CONCLUSIONS}

Callogenesis occurred on $98.83 \%$ of coconut endosperm explants. Calli browning increased significantly from 9 to 21 WOC but not thereafter. Browning of antipodal tissue-derived calli was more significant at 9,26 and 31 WOC but not at 16 and 21 WOC compared to micropylar tissues. Treatments of 2,4-D and Picloram did not 
affect calli browning. Auxins at 0 and $10^{-3} \mathrm{M}$ produced significantly more callus browning than other doses at 9 and 16 WOC. Auxins of $10^{-6} \mathrm{M}$ produced significantly less callus browning than other doses at 21 WOC. Calli browning was more intense at $10^{-5} \mathrm{M}$ auxins at $26 \mathrm{WOC}$. Auxins of $10^{-3} \mathrm{M}$ produced significantly less callus browning than other doses at $31 \mathrm{WOC}$. Addition of cytokinin BA produced significantly more callus browning at $16 \mathrm{WOC}$ but not thereafter.

\section{ACKNOWLEDGEMENTS}

The author would like to thank Dr. Y. Sagawa and Dr. D.T. Webb for their advice, while Mr. R. Wutzke for providing the experiment The Overseas Training Office/ Badan Perencanaan Pembangunan Nasional (BAPPENAS) - Indonesia is acknowledged for the funding support.

\section{REFERENCES}

Abdelwahd R, Hakam N, Labhilili M, Udupa SM. 2008. Use of an adsorbent and antioxidants to reduce the effects of leached phenolics in in vitro plantlet regeneration of faba bean. African J Biotech 7(8):9971002

Alderson PG. 1987. Micropropagation of woody plants. In: Alderson PG and Dullforce WM (editors). Micropropagation in Horticulture, Practice and Commercial Problems. The Univ. Nottingham Trent Print Unit. p 37-52

Babbar SB, Gupta SC 1986. Induction of androgenesis and callus formation in in vitro cultured anthers of a myrtaceous fruit tree (Psidium guajava L.). Bot Mag Tokyo 99:75-83

Bhaskaran S. 1985. Tissue culture technology for higher vegetable oil production. In: Srivastava, HC, Bhaskaran S, Vatsya B, Menon KKG (editors). Oilseed production: Constraints and Opportunities. Oxford \& IBH Publishing Co., New Delhi. p 537-544

Beyl CA, Sharma GC. 1983. Picloram induced somatic embryogenesis in Gasteria and Hawortbia. Plant Cell Tissue Organ Cult 2:123-32.

Bhat S.R, Chandel KPS. 1991 A novel technique to overcome browning in tissue culture. Plant Cell Rep 10:358361.

Blake J, Eeuwens CJ. 1982. Culture of coconut palm tissues with a view to vegetative propagation. In: Rao A.N. (editor). Tissue Culture of Economically Important Plants. Proc Int Symp. Singapore. p 145-48

Branton RL, Blake J. 1986. Clonal propagation of coconut palm. In: Pushparajah, E，Chew PS (editors). Cocoa and Coconut: Progress and Outlook. Incorporated Society of Planters, Kuala Lumpur. p 771-79.

Chang SH, Ho CK, Chen ZZ, Tsay JY. 2001. Micropropagation of Taxus mairei from mature trees. Plant Cell Rep 20:296-502.

Cheema GS, Mehra PN. 1982. Morphogenesis in endosperm cultures. In: Fujiwara, A. (editor). Plant Tissue Culture 1982. Proceedings of the 5th International Congress of Plant Tissue and Cell Culture. Tokyo p. 111-12.

Chen RZ, Li GG, Zhang LY, Kuo CY. 1990. Somatic embryogenesis of endosperm of sweet orange (Citrus sinensis cv. 'Hongiang') in vitro culture. In: Proc. Int. Citrus Symp. Guangzhou, China. p 182-87

Christianson ML, Warnick DA. 1983. Competence and determination in the process of in vitro shoot organogenesis. Dev Biol 95:288-93. 
Compton ME, Preece JE. 1988. Response of tobacco callus to shoot tip exudation from five species. HortScience 23(1):208-10

Davies ME. 1972. Polyphenol synthesis in cell suspension cultures of Paul's Scarlet rose. Planta (Berl.) 104:50-65

Dias AC, Guerra MP, Cordoba AS, Kemper EL. 1994. Somatic embryogenesis and plant regeneration in the tissue culture of Geonoma gamiova (Arecaceae). Acta Hort 360:167-71

Eeuwens J. 1978. Effects of organic nutrients and hormones on growth and development of tissue explants from coconut (Cocos nucifera). and date (Phoenix dactylifera) palms culture in vitro. Physiol Plant 42:173-78

Ettinger TL, Preece JE. 1985. Aseptic micropropagation of rhododendron P.J.M. hybrids. J Hort Sci. 60(2):26974

Everett NP, Wang TL, Street HE. 1978. Hormone regulation of cell growth and development in vitro. In: Thorpe TA (editor). Frontier of Plant Tissue Culture. The Int. Assoc. for Plant Tissue Culture Publisher, Calgary, Canada. p 307-16

Fitch MM, P Moore PH, Irvine JE. 1983. The use of picloram for maintenance of regenerative callus lines in long-term tissue culture of sugarcane. Plant Physiol (suppl) 72(1):46

Forrest GI. 1969. Studies on the polyphenol metabolism of tissue cultures derived from the tea plant (Camellia sinensis L.). Biochem J 113:765-72

Fridborg G, Pedersen M, Landstrom L, Eriksson T. 1978. The effect of activated charcoal on tissue cultures: adsorption of metabolites inhibiting morphogenesis. Physiol Plant 43:104-06

Gmitter FG Jr, Ling XB, Deng XX. 1990. Induction of triploid Citrus plants from endosperm calli in vitro. Theor Appl Genet 80:785-90

Guo XL, Zhang ZY, Wang XD, Ren FZ, Jie B, Chen F. 2010. Overview of tissue culture of azaleas. Http://eng.hi138.com/?i252627_Overview_of_tissue_culture_of_azaleas. Accessed on December 21,2010

Herve P, Jauneau A, Paques M J. Marien J, Bodet AM，Teulieres C. 2001. A procedure for shoot organogenesis in vitro from leaves and nodes of an elite Eucalyptus gunnii clone: comparative histology. Plant Sci 161(4):645-53

Jesty JHF, Francis D. 1992. Cellular responses of leaf explants of Cocos nucifera L. in vitro. Plant Cell, Tissue and Organ Culture. 28:235-44

Jones LH. 1974. Propagation of clonal oil palms by tissue culture. Oil Palm News 17:1-8.

Karunaratne S, Periyapperuma K. 1989. Culture of immature embryos of coconut, Cocos nucifera L.: callus proliferation and somatic embryogenesis. Plant Sci 62:247-53.

Karunaratne S, Gamage C, Kovoor A. 1991. Leaf maturity, a critical factor in embryogenesis. J Plant Physiol 139:27-31

Krikorian AD. 1994. In vitro culture of plantation crops. In: Vasil IK, Thorpe TA(edsitors). Plant Cell and Tissue Culture. Kluwer Academic Publishers, Dordrecht, Boston and London. p 497-537.

Krishna H, Sairam RK, Singh SK, Patel VB, Sharma RR, Grover M, Nain L, Sachdev A. 2008. Mango explants browning: Effect of ontogenic age, mycorrhization and pre-treatments. Scientia Horticulturae $118(2): 132-38$

Kumar PP, Raju CR, Chandramohan M, Iyer RD. 1985. Induction and maintenance of friable callus from the cellular endosperm of Cocos nucifera L. Plant Sci 40:203-207

Kuruvinashetti MS, Iyer RD. 1980. Tissue culture studies on cocout palm for its clonal propagation. In: Rao PS, Heble MR, Chadha MS (editors.). Proc Nat Symp Plant Tissue Culture, Genetic Manipulation and Somatic Hybridization of Plant Cells. Bombay. p 184-91

Litz E. 1988. Somatic embryogenesis from cultured leaf explants of the tropical tree Euphoria longan Stend. J Plant Physiol 132:190-93

Misra, Toppo DD, Gupta N, Chakrabarty D, Tuli R. 2010. Effect of antioxidants and associate changes in antioxidant enzymes in controlling browning and necrosis of proliferating shoots of elite Jatropha curcas L. 2010. Biomass and Bioenergy 34(12):1861-9 
BIOTROPIA Vol. 18 No. 1, 2011

Mitsukuri K, Mori G, Johkan M, Shimada Y, Mishiba KI, Morikawa T, Oda M. 2009. Effects of explants position and dark treatment on bud formation in floret culture of Ponerorchis graminifolia Rchb.f. Scientia Horticulturae 121(2):243-47

Mu SK, Liu SC. 1978. Cytological observation calluses derived from apple endosperm cultured in vitro. In: Proc Symp Plant Tissue Culture. Science Press, Peking, China. p 507-10

Murashige T. 1974. Plant propagation through tissue cultures. Ann Rev Plant Physiol 25: 135-66

Omar MS, Novak FJ. 1990. In vitro plant regeneration and ethylmethanesulphonate (EMS) uptake in somatic embryos of date palm (Phoenix dactylifera L.). Plant Cell Tissue Organ Cult 20:185-90.

Ozyigit IL, Kahraman MV, Ercan O. 2007. Relation between explant age, total phenols and regeneration response in tissue cultured cotton (Gossypium birsutum L.). African J Biotech 6(1):003-008.

Pannetier C, Buffard-Morel J. 1982. Premiers resultants concernant la production d'embryons somatiques a partir de tissues foliaires de cocotier, Cocos nucifera L. Oleagineux 37(7):349-53

Pannetier C, Buffard-Morel J. 1986. Coconut palm (Cocos nucifera L.) In: Bajaj YPS. (editor). Biotechnology in Agriculture and Forestry, Vol. 1: Trees I. Springer-Verlag, Berlin. p 430-50

Paranjothy K, Rohani O. 1982. In vitro propagation of oil palm. In: Fujiwara A. (editor). Plant Tissue and Cell Culture 1982. Proc $5^{\text {th }}$ Int Cong Plant Tissue and Cell Culture, Tokyo and Lake Yamanaka, The Japanese Association for Plant Tissue Culture, Japan. p 747-48

Paranjothy K. 1986. Recent developments in cell and tissue culture of oil bearing palms. PORIM Occasional Paper 19:1-12

Phillips R, Henshaw GG. 1977. The regulation of synthesis of phenolics in stationary phase cell cultures of Acer pseudoplatanus L. J Exp Bot 28(105):785-94

Preece JE, Compton ME. 1991. Problems with explant exudation in micropropagation. In: Bajaj YPS (editor). Biotechnology in agriculture and Forestry, Vol 17: High-tech and Micropropagation I. Springer-Verlag, Berlin.p 168-89

Rao PS, Sreadhar D, Mathews VH. 1987. In vitro multiplication of oil palm (Elaesis guineensis Jacq). In: Reddy GM (editor). Plant Cell Tissue Culture of Economically Important Plants. Department of Genetics, Osmania Univ, Hyderabad, India. p. 209-13

Reynolds JF. 1982. Vegetative propagation of palm trees. In: Bonga JM, Durzan DJ(editors). Tissue Culture in Forestry. Martinus Nijhof/ dr. W. Junk Publisher, The Hague. p 182-207

Sharma DR, Dawra S, Chowdhury JB. 1984. Somatic embryogenesis and plant regeneration in date palm (Phoenix dactylifera Linn.) cv. Khadravi through tissue culture. Indian J Exp Biol 22:596-98

Skoog F, Miller CO. 1957. Chemical regulation of growth and organ formation in plant tissues cultured in vitro. Symp Soc Exp Biol 11:118-40

Srinivasan C, Litz RE, Barker J, Norstog K. 1985. Somatic embryogenesis and plantlet formation from christmas palm callus. HortScience 20(2):278-80

Srivastava PS. 1982. Endosperm culture. In: Johri BM (editor). Experimental embryology of vascular plants. Springer-Verlag, Berlin. p 175-93

Sugimura Y, Salvana MJ. 1989. Induction and growth of callus derived from rachilla explants of young inflorescences of coconut palm. Can J Bot 67(1):272-74

Tammes PML, Whitehead RA. 1969. Coconut, Cocos nucifera L. In: Ferweda, F.P. and F. Wit (editors.). Outlines of Perennial Crop Breeding in the Tropics. Veenman \& Zonen N.V. Wageningen. p. 175-88

Tang W, Newton RJ. 2004. Increase of polyphenol oxidase and decrease of polyamines correlate with tissue browning in virginia pine (Pinus virginiana Mill.). Plant Sci 167(3):621-28

Thomas TD. 2008. The role of activated charcoal in plant tissue culture. Biotechnology Advances 26(6):618-31

Tisserat B. 1979. Propagation of date palm (Phoenix dactylifera L.) in vitro.J Exp Bot 30(119):1275-283

Trautmann IA, Visser JH. 1991. The possible role of phenolic substances in the establishment of suspension cultures of guayule (Parthenium argentatum Gray). Bioresource Technology 35(2):133-39 
Valverde R, Arias O, Thorpe TA. 1987. Picloram-induced somatic embryogenesis in pejibaye palm (Bactris gasipaes H.B.K.). Plant Cell Tissue Organ Cult 10:149-56

Verdeil JL, Buffard-Morel J, Pannetier C. 1989. Embryogenese somatique du cocotier (Cocos nucifera L.) a partir de tissues foliaires et inflorescenciels. Bilan des recherches et perspectives. Oleagineux 44(8-9):403-11

Verdeil JL, Huet C, Grosdemange F, Buffard-Morel J. 1993. Plant regeneration from cultured immature inflorescences of coconut (Cocos nucifera L.): evidence for somatic embryogenesis. Plant Cell Rep 13:218-21

Wang TY, Huang LC. 1976. Beneficial effects of activated charcoal on plant tissue and organ cultures. In vitro $12(3): 260-62$

Wang TY, Chang CJ. 1978. Triploid Citrus plantlet from endosperm culture. In: Proc Symp on Plant Tissue Culture. Science Press, Peking, China. p 463-67

Wu,HC, du Toit ES. 2004. Reducing oxidative browning during in vitro establishment of Protea cynaroides. Scientia Horticulturae 100(1-4):355-58

Wu QY, Xu LY, Gong LG. 2010. Qing Qian Liu different explants on tissue culture and the prevention of browning. Http://eng.hi138.com/?i131358. Accessed on December 21, 2010

Zhu,YM, Hoshino Y, Nakano M, Takahashi E, Mii M. 1997. Highly efficient system of plant regeneration from protoplasts of grapevine (Vitis vinifera L.) through somatic embryogenesis by using embryogenic callus culture and activated charcoal. Plant Sci 123(1-2):151-57 